\title{
Errata to the Stanisław Czernik's Biography: 1949
}

Stanisław Czernik (1899-1969), a writer, poet and commentator, somewhat forgotten today, had an extraordinary life. He was born in Zochocin near Opatów where he attended the Opatów Municipal School. He went on to graduate from the Teachers' College in Jędrzejów and the Rescue Committee Middle School in Olkusz. In 1918, he enlisted but was later discharged from the army for his poor health. After 1920 he worked as a teacher in several public schools. He simultaneously studied at The University of Poznan, graduating in 1925 from the Faculty of Law and Economics. He made his début in 1922 with an article published in Życie szkolne. While living in Gostyń he was editor-in-chief first of "Głos Gostyński" and later of "Ziemia Gostyńska". In 1926, he returned to working as a teacher. In 1931-1932, he fulfilled the function of headmaster at the Humanities Middle School in Ostrzeszów. In the early-1930s, he focussed on his creative work publishing in numerous journals. He wrote articles, reviews, prose pieces, and translated foreign texts. In 1939, Stanisław Czernik participated in the September Campaign. Later he emigrated to Algiers through Romania, where he spent six years. He was the headmaster of the Polish Middle School and High School. After WWII, he lived in Italy and England, where he also fulfilled the function of a headmaster. In 1947, he returned to Poland and in 1948-1951 he worked as a senior advisor and manager of the Office of Original Output at the Department of Artistic Output of the Ministry of Culture and Arts.

This article shall discuss only a small section (the year 1949) of the life of the founder of authenticism. According to a study entitled Wspótcześni polscy pisarze $i$ badacze literatury [Contemporary Polish writers and literary scientists], upon his arrival in Poland after WWII, Stanisław Czernik published three books: Siedem nocy [Seven Nights] (a poetry collection, 1948), Bezprym. Dramat w 3 aktach

* Mgr, e-mail: wiktorgardocki@o2.pl; University of Bialystok, Faculty of Philology, Institute of Polish Philology, 15-420 Bialystok, ul. Plac Uniwersytecki 1.

${ }^{1}$ K. Jakowska, Podręczny stownik pisarzy polskich, Warsaw 2006, pp. 101-102; P. Kuncewicz, Leksykon polskich pisarzy współczesnych, vol. 1, A-M, Warsaw 1995, pp. 169-170; Stownik pisarzy polskich, E. Zarych (ed.), Cracow 2008, p. 91; Współcześni polscy pisarze i badacze literatury, J. Czachowskiej i A. Szałagan (eds.), vol. 2, C-F, Warsaw 1994, pp. 106-109. 
[Bezprym. A Drama In Three Acts] (1949) and Smolarnia nad Bobrowa Woda. Powieść historyczna $z$ XI wieku [Wood Tar Factory on the Bobrowa Woda. An $11^{\text {th }}$ Century Historical Novel] (1949). In the meantime, he submitted to the publishing house at least three more compositions.

Before the book was published the typescript was sent for review to the Main Office of Control of Press, Publications and Shows (GUKPPiW). In the event of a negative review, an appeal was possible: through the Department of Artistic Output of the Ministry of Culture and Arts (MKiS) or through the Polish Writers' Union. It is difficult, however, to trace, at least in the case of 1949, the precise process of the publication of Stanisław Czernik's works because of gaps in the documentation. It is possible that publishing houses submitted his books with the Main Office of Control of Press, Publications and Shows; any records, though, have not been found. But MKiS documents have survived. The probability of the typescripts of Czernik's works being sent directly to MKiS, and omitting GUKPPiW, is rather low, but such a possibility cannot be rejected altogether. What is interesting is that his works were reviewed by the institution of which he himself was an employee.

It is worth studying how state officers, employed at the same institution as Czernik, evaluated his works. All the reviews referred herein can be found in a single file in the Archives of New Records (AAN) ${ }^{2}$.

In 1949, Czernik finished, among other works, the drama entitled Bezprym. Since the reviewer's ${ }^{3}$ evaluation completed in March of the same year indicated that the work had no value whatsoever, it is surprising that it was one of the few that actually got published at that time. When issuing her review, the officer used the reviewer form applicable at that time, which clearly stated features which a work was required to include. The form included such points as: "the manner in which the topic is approached", "environment", "time period" and many more to prevent a reviewer from omitting any significant issues. Thus, the officer accused Bezprym of "a lack of clearly stated theme" adding that "the drama is not politically destructive". Since the action takes place in the $11^{\text {th }}$ century, emphasising the latter seems a result of excessive meticulousness. The officer also referred to the theme of religion ("unclear position") and the possible social resonance ("none"). To the question "what is the preferred group of readers of the book" she concluded tersely: "no one"4. Yet the most expressive and outright opinion was stated in the field "artistic value" where the reviewer noted: "Mediocre. Topic has not been exhausted. Superficial approach and lack of material attitude to the topic. On the whole, vapid and uninteresting". Finally, in the "final proposal justification" she stated: "No one needs a tragedy approached in this manner and it cannot be staged anywhere". In order to dispel

${ }^{2}$ AAN, Ministry of Culture and Arts, Department of Artistic Output, Publishing Division, ref. no. 704, no pagination (reviews are organised according to the names of authors of the works).

${ }^{3}$ Her name could not be identified because of illegible handwriting.

${ }^{4}$ Under "no one" there are also some illegible notes written in fountain pen. 
any lingering doubts, the "final conclusion" field also included a negative opinion. It would seem that such a crushing assessment of Czernik's work would, at least for some time, condemn Bezprym to non-existence, but it was sent for a secondary review with a note... "positive". Since the form includes sentences written using a typewriter as well as hand-written sections (using a fountain pen and red pencil) it is difficult to conclude what was the cause of this sudden change. The section "Motion of the Publishing Division" of the form includes a note: "considering the work is not destructive: positive". Unfortunately, the brief note does not explain anything.

Another work by Czernik published in 1949 was Smolarnia nad Bobrowa Woda, a historical novel which, similarly to Bezprym, took place in the $11^{\text {th }}$ century. That publication proposal was evaluated by Zofia Banaszkiewicz on 11 February of that year. She evaluated its level as average and she proposed some corrections. She was, for example, disturbed by... the character of a Hindu fakir who possessed "supernatural powers". She also noted that "the book is politically neutral, i.e. it is not destructive nor does it include any new progressive approach towards the past". Apart from that, being a "good historical read" though "free of any major value", it could be recommended to all readers. As a result, the reviewer stressed: "fit for publication upon introduction of corrections". The review form also includes a signature of another person, probably by the name of Michalski. The signature is located where Banaszkiewicz granted the work a positive evaluation.

In the same year, Stanisław Czernik submitted to the publishing house. The novel received two reviews from the Ministry of Culture and Arts. The first, by $\mathrm{H}$. Wielowiejska, was definitely favourable. The reviewer emphasised the presence of positive characters in the novel and the promotion of values despite the rather sensitive nature of the place and time of action (1939 Polish-German borderlands. The review was positive for Czernik: "the novel, being proper in terms of its literariness, should be published". The book, unequivocally for "all adult" readers, "deserves to be published" in the eyes of Wielowiejska. The reviewer's evaluation was shared by the Publishing Division of MKiS; the form bears a note: "positive". Unfortunately, as there is no date stated, it cannot be concluded when the review was written.

Neither was the second review of Wichura marked with a date. It was created by Michał Szułaga. Interestingly enough, the officer received a 136-page copy of the typescript while Wielowiejska received a 138-page copy. The reviewer spent a large portion of the review on summarising the novel and finally drew the following conclusions:

The book suggests Nazi theories. It does not pose any major artistic value. Promoting biological hatred towards all Germans is also untimely ${ }^{5}$.

${ }^{5}$ AAN, Ministry of Culture and Arts, Department of Artistic Output, Publishing Division, ref. no. 707, no pagination (reviews are organised per the names of authors of the works). 
At this point, it is interesting to quote Wielowiejska, who evaluated the novel in this respect quite differently:

(...) there is no nationalism present. And Germans have honest reactions, like Fryderyk, in any case, the best example (...) is the character of a young German communist who joins partisan forces or the underground to fight the Nazis ${ }^{6}$.

Szułaga concluded his review by stating that it "does not deserve to be published". Nonetheless, the "Motion of the Publishing Division" section of the form includes a note "positive". Eventually, Wichura was not published until 1958. In this case one might assume the novel was sent to GUKPPiW where it was rejected only to be permitted for printing after several years.

The next two works by Czernik submitted for publication in 1949 are nowhere to be found in the Wspótcześni polscy pisarze i badacze literatury study or Polskiej Bibliografii Literackiej [Polish Literary Bibliography]. The first one was Aparat Jasia Kowasia [Jaś Kowaś' Apparatus]. A summary of it created by a reviewer is worth quoting at this point:

Four Adams and one Jaś decided to build an apparatus. They established a small cooperative so that they could [illegible word] and they invited Zosia, who had a wooden board, which was necessary to build the apparatus.

A very beautiful and precise apparatus was constructed and only then did they start wondering what might its usage be. Jaś Kowaś [illegible] them: for studying what people have in their heads. It turned our Zosia was thinking about a tasty dinner. Four Adams run away unwilling to undergo the test. Jaś remained alone and dreamt of giving the invention to [illegible]. To the Academy for the benefit of the entire world and the glory of Poland. But suddenly the apparatus fell and broke on a stone. And Jaś was woken up because it was already late and he had to get up to go to school. The wonderful invention is a dream of a boy who had a passion for technical sciences?

Aparat Jasia Kowasia has a verse form, was nine-pages long and was written, according to the reviewer, for children aged 7-10 years of age. The officer, whose signature is illegible, issued a positive evaluation, dated 28 October 1949. Regardless of the positive review, the work has probably never been published. It has not been recorded in any available study. Of course, it is possible that it passed unnoticed in some lesser known magazine.

The review form of Aparat Jasia Kowasia included an attached "card of book submitted for publication". It becomes even more interesting considering that,

\footnotetext{
${ }^{6}$ Ibidem.

${ }^{7}$ Ibidem.
} 
based on the document, the composition was submitted for publication while bypassing GUKPPiW or it was not even submitted, thus not engaging the unit at all. The card is blank, it only includes (again illegible) the name of the reviewer, book details, name of publishing house (Krakow-based Wydawnictwo Książek Popularnych), the date of submitting the composition with the Department of Artistic Output and the date of notifying the publisher about the decision which is unknown today as it was not recorded on the card. The composition is rather short, however, according to MKiS material, it was planned to be published as a separate book.

Considering the fact that Aparat... was written in 1949, there is a chance it was published in the press. Any search is hampered by the fact that at the turn of 1950 Czernik was not affiliated (at least no one indicated that) with any literary journal. If it was not published anywhere, it can be treated as inedita. Additionally, it would be an undeniable literary discovery to locate the text of the work.

In 1949, Biblioteka Dzieł Wybornych [Library of Excellent Works] expressed a will to publish Stanisław Czernik's 50-page drama entitled Wielkie powroty [Great Returns]. The date when the typescript was submitted with MKiS remains unknown, however, it is known that the reviewer received it on 2 February and he issued his report on the $25^{\text {th }}$ of the same month. Just as in the case of Aparat... Wielkie powroty were also not recorded in the Wspótcześni polscy pisarze i badacze literatury study. It is highly probable that the composition was not announced anywhere. Thus, it is worthwhile to know its plot:

In a village in Regained Territories mutual aversion of the local population and the newcomers from the East clash. A local by the name of Kukuła dislikes Poles who humiliate him by calling him "German". He is local. Neither Polish nor German. His son Janek already feels Polish, his other son Fryderyk is near Berlin and is supposed to marry a German woman, which aches his father. There are, however, v. valuable people among the Poles and Kukuła begins to like them. He warms up to Jagusia, who loves rabbits just like his Fryderyk, the teacher who wisely solves the conflict between the man and his son and Żarecki suffering from "linden". By spending time with the Jew Różycki he also changed his view about the Jewish issue. Kukuła finally accepts the reality he lives in but wishes that Fryderyk came back to the land. So he writes him a letter, forbids him from getting married and orders him to return. But he does not receive any answer.

On Kukuła's $50^{\text {th }}$ birthday, guests come bringing him their wishes. Janek and Kasia, the teacher's daughter, have been friends for a long time and they prepare the party together. The guests arrive and according to the old Kukuła custom are greeted with beer and cheese. Suddenly, Fryderyk arrives who understood his marriage with the German woman would not bring him happiness, so he broke up with her and returned to his people. 
And thus great returns take place. Silesia returns to Poland, Poles return to Regained

Territories, Fryderyk returns to his hut and Różycki wishes to return to the land of his fathers to which he remained faithful for 2000 years ${ }^{8}$.

The reviewer believed that the book was very helpful as "the local people in R.T. are very valuable individuals and they should be treated with respect and love". He also stated that the drama should also reach the largest possible group of readers. He praised its composition, dialogues, linguistic flawlessness and "the feel of the stage". He considered the artistic value of the drama as "high". He proposed, changes, though minute, to the story, but since the work is not currently available there is no point in quoting them. The reviewer's decision was positive.

Another officer reporting on Wielkie powroty, apart from summarising the plot, formulated several conclusions. He wrote, that "the story about the spiritual changes of old Kukuła is not convincing" and he noted that the writer was not able to "truly" present the change. He considered other characters of the play as "artificial and paper thin". Only Fryderyk's story could constitute a "surprise" for the reader, though in that instance as well, the "artificial" nature is striking. Summing up the officer wrote: "almost no social and political focus, though there was a place for it [reviewers underscore]. The play is not fit for publication (because of the above reasons). It is redundant, though the topic raised by the author is interesting and current". The reviewer's name and the issue date of the evaluation remain unknown.

Wielkie powroty have probably never been printed. Just as in the case of Aparat... they might have appeared in a journal and therefore the title was not included in Współcześni polscy pisarze i badacze literatury or Polska Bibliografia Literacka studies. One cannot even state for certain whether Wielkie powroty have ever been staged. Whether the typescript of the play has survived remains unknown.

What is interesting is the question of the extent that Stanisław Czernik's employment at the Ministry of Culture and Arts influenced the way in which his works were treated. The reviews, some more some less careful, seemed objective. The officers, since they knew whose work they were evaluating, probably did not give it a "free pass". If a piece turned out inferior, they simply issued a negative evaluation. The only unclear situation occurred in the case of Bezprym, a play almost completely crushed by the reviewers eventually was published the same year (1949). Other works, however, which were evaluated positively have never seen the light of day. Two of those, in the light of available documents, could be considered as inedita.

\footnotetext{
${ }^{8}$ Ibidem.

${ }^{9}$ Ibidem.
} 
In the Stanisław Czernik case, when considering 1949, something else is extraordinary: the writer, an employee of the Ministry of Culture and Arts at that time, worked at a department which reviewed his works. A folder marked 704 includes, together with seven reviews of works by Czernik, reviews of other work; this time the reviews were written by Czernik.

He reviewed Zygzaki [Zigzags] by Antoni Bernat, Antologia o matce i dziecku [Anthology On The Mother And Child] by Jan Bersa, Żyto kwitnie [Secale Is Blooming] by Jerzy Bińczak, Żywe ściegi [Live Stitches] by Kazimierz Czachowski, Jak patrzeć na teatr [How To Perceive Theatre] by Edward Csato, Branki w Jasyrze [Women In Jassir] by Jadwiga Łuszczewska (a.k.a. Deotyma), Święty miecz [Holy Sword] by Jan Dobraczyński, Dzieje polskości miasta Zabrza [The History Of Polishness Of The City Of Zabrze] by Paweł Dubiel, Wolni i plemie jaszczurze [The Free And The Lizard Tribe] by Jan Gaweł, Les jours maigres by Georges Govy and Przyroda w twórczości Elizy Orzeszkowej [Adventure In The Works By Eliza Orzeszkowa] by Bolesław Hryniewski.

He was a very factual and meticulous reviewer, best confirmed by his carefully filled out forms. He never refrained from issuing stern opinions, sometimes clearly indicating that a given book was not worth much.

When discussing Czernik's reviews one must start with establishing what, in his opinion, was most interesting. Even though there are no studies which could confirm this, it can be assumed that Stanisław Czernik fulfilled the function of manager of the Office of Original Output at the Department of Artistic Output of the Ministry of Culture and Arts in 1948-1951 not by accident. Who else then knew more about folklore and peasant output that the initiator of authenticism.

On 28 February 1949, Czernik received for review a collection of poems by Józef Bińczak entitled Żyto kwitnie. This was how the writer-officer described that collection:

It is a début of a typical "original" talent. The author, living in the countryside, without any scientific background, has been writing poetry for over twenty years. Before WWII he did not have the chance to perfect his work and so he wrote emulating former folk poets, such as Antek z Bugaju or Fryderyk Kuraś. Only after WWII did Bińczak gain the proper circumstances for considerable development and managed to reach an artistic level within a modest yet characteristic scope.

The collection consists of wartime and personal poems and pastorals ${ }^{10}$.

Stanisław Czernik emphasised that the artistic value of the book was "medium", nonetheless it "deserves to be published". He stressed: "Bińczak's début is another very characteristic proof of the possibility of artistic development of

${ }^{10}$ Ibidem. 
peasant poets in the altered circumstances of the present day". His opinion was surely a major reason why the book was published under the same title as in the application already in 1949. The author later published a few more works.

The literary career of Antoni Bernat was quite different. His book was sent to the Ministry of Culture and Arts, probably relegated by GUKPPiW (the review form states GUKPPiW as the publisher, which obviously was not true - it probably indicated the previous institutions that reviewed Bernat's book). Stanisław Czernik received Zygzaki on 25 March 1949. The collection, according to the description by the reviewer, consisted of three parts: "serious" poems, erotic poems and satires. Additionally, the collection was preceded by a foreword where Bernat vigorously criticised Konstanty Ildefons Gałczyński and Władysław Broniewski. The evaluation of Zygzaki issued by Stanisław Czernik was crystal clear:

In general, the author possesses mediocre poetic skills. Some of the initial poems indicate that had he applied strict discipline, he would have had achieved some results. Unfortunately, when it comes to erotic themes, he falls for banality resembling "candy" poems. The satirical and humorous poems are insipid, some of them could, at the most, be used in some inferior humorous magazines, but do not deserve to be published as a book, and on top of that the author's lack of good manners results in such improper behaviour as, e.g. wishing Broniewski to die ("Starszemu Panu" [To The Elderly Gentleman], p. 36) ${ }^{11}$.

Zygzaki has never been published and Antoni Bernat, who in Polska Bibliografia Literacka was not even mentioned once, has never been recognised as a writer. His name has never appeared in the index: neither before nor after 1948. The main reason for that was probably his lack of talent, as indicated in Stanisław Czernik's review. Antoni Bernat did not publish Zygzaki because of its political content, but because of its low artistic value. Unfortunately, the collection's typescript is not available in the files of the former MKiS.

Another book reviewed by Czernik in 1949 which is worth considering was Antologia o matce $i$ dziecku by Jan Bersa, another writer that has never gained any acclaim, though the reviewer in his evaluation did not exclude the chance of his finding success in the future. Bersa's collection, as Czernik described it, consisted of poetic works, prose fragments as well as aphorisms and maxims. However, he noted that:

Arrangement of poems random. The author appears to have used some thematic criteria but it is not visible anywhere. The selection of poems and authors raises some doubts. Several unknown authors: Kazimierz Siwiński, Kazimierz Skowroński, Ed-

${ }^{11}$ Ibidem. 
ward Chłopicki. Their poems are rather trivial and should not be included in the anthology. (...) poems inferior in terms of their artistic value raise doubts, e.g. the poems by Elżbieta Szemplińska and Felicja Kruszewska. A fragment of the Prologue of Part III of Dziady is too artificially extracted from the whole. Certain reverence towards Mickiewicz prohibits this kind of mutilation of works ${ }^{12}$.

Stanisław Czernik did actually see a way to publish the anthology but proposed radical changes, for he understood the sensibility required for publication. The collection could not include works selected at random and it should be edited by, in the words of the reviewer, "a good literary critic".

The story of another proposed publication, a collection of articles of literary critics entitled Żywe ściegi by Kazimierz Czachowski, is also intriguing. Theoretically, there should have been no problem publishing the book. Its late author (1948) was, at that time, an acclaimed writer, who had worked in the Ministry of Culture and Arts. In 1945-1946, Czachowski fulfilled the function of director of the Department of Literature and the Office for International Cultural Cooperation ${ }^{13}$.

Stanisław Czernik evaluated Żywe ściegi unequivocally positively. He stressed the lack of good "critical and informative" publications on the market; Czachowski's book, being a follow-up to Obraz wspótczesnej literatury polskiej [Image of contemporary Polish literature] and Najnowsza polska twórczość literacka [Latest Polish literary output] by the same author, could change this state of affairs. However, some remarks in Czernik's review were puzzling:

Particularly interesting are post-WWII articles, especially the study opening the book entitled "Zamówienie społeczne w literaturze" [Social commission in literature] (1947). It is an argumentative articles in which the author stands against the "officious" understanding of the relationship between literature and life. The author thus expresses his final view: "The state and the society should care for arts, yet they cannot interfere with the process of artistic creation. One should never forget that managed art stops being art and the artist who lacks the sense of artistic freedom ceases to be an artist ${ }^{14}$.

Regardless of how one approaches this quote, it becomes obvious that by placing it in the review form section entitled "short plot" the reviewer was clearly attacking censorship. In short, Czernik summarised the very essence of what, had he wanted to have a positive influence on the decision of the Division, he should not have stated. It is obvious that the Ministry would not "let through" a publication

\footnotetext{
12 Ibidem.

${ }^{13}$ Wspótcześni polscy pisarze..., p. 76.

${ }^{14}$ AAN, Ministry of Culture and Arts, Department of Artistic Output, Publishing Division, ref. no. 707.
} 
proposal, even one which received a positive evaluation, if it remained in opposition to the censorship policy and Socialist realism, just emerging at that time in Poland (1949). The following fragments, even though free of any critical statements, were quite straightforward for the reader of the review:

(...) the following studies: "Sztuka organizuje narodową wyobraźnię" [Art organising national imagination] (1945) and "Literatura a życie" [Literature and life]. The author emphasises the irrational factor in art and literature thus approaching the issue: "In the most practically regulated social life it is necessary to give some leeway for irrational factors through which we release ourselves, even for a moment, from the shackles of worldliness to be able to admire beauty, rise above one's personal needs and extent one's imagination towards what is unknown, mysterious and remote"15.

The above words, when juxtaposed against the contemporary social and political situation, where a rather poor attempt at promoting the book. The situation did not improve much with other sections of the book, which, as Czernik noted, were devoted to: "the output of specific authors from 1937-39". Thus, a work whose artistic value was supposed to be undeniable and unequivocally fit for publication, eventually was not published; and the positive review in fact became... negative. The review form included a postscript "negative" and a signature, which means Czernik's evaluation was revised.

It would be difficult to assume that Czernik purposefully wrote his review to both positively recommend the project and send a clear message that it should not be continued. If that had been the case, he would have probably written that $\dot{Z} y w e$ ściegi is, indeed, a valuable read, but in the face of literature which is supposed to be "close to reality", to publish it would be dangerous; he would have possibly recommended to remove the most "drastic" articles, thus salvaging the less controversial ones. It may be the case that when he was reviewing it (15-31 March 1949) Czernik did not yet have detailed guidelines as to what deserved particular attention; thus, the puzzling undertone of his review. The form also included a subsection "social and political views suggested by the author". Czernik wrote there:

The author declares he supports contemporary transformations in literature and art, but he emphasises his personal views similar to the concepts of French intellectuals seeking synthesis and practical solutions to the antinomies of contemporary world ${ }^{16}$.

The above opinion seems to be meticulous and factual, but it applied to the artistic attitude of the author of $\dot{Z} y w e$ ściegi. The fact that Czernik knew that

\footnotetext{
${ }^{15}$ Ibidem.

${ }^{16}$ Ibidem.
} 
both realms (artistic and "social-political") could not be viewed separately suggests that he must have had some guidelines. How extensive their influence on his evaluation and the shape and the "odd" undertone of the review was remains unknown.

Fortunately, the majority of Czachowski's works proposed for publication were published in journals before WWII and they managed to reach at least a portion of the readers.

The case of Stanisław Czernik: a writer, reviewer and an employee of the Ministry of Culture and Arts, perfectly illustrated the state of affairs in Polish literature at the turn of the 1950s. He was a well-known writer who was artistically active after WWII on the one hand but a reviewer on the other. He was the one who evaluated and who was evaluated by others.

This study constitutes a first step into further research and surely does not exhaust the topic, more so considering the fact that the Archives of New Records and, probably, other institutions still hold much valuable material which still remain undiscovered.

\section{Bibliography}

AAN, Ministry of Culture and Arts, Department of Artistic Output, Publishing Division, ref. no. 704. AAN, Ministry of Culture and Arts, Department of Artistic Output, Publishing Division, ref. no. 707. Czernik Stanisław, Bezprym: dramat w trzech aktach, Centralna Księgarnia Rolnicza, Warsaw 1949. Czernik Stanisław, Chłopskie pisarstwo samorodne, Państwowy Instytut Wydawniczy, Warsaw 1954. Czernik Stanisław, Smolarnia nad Bobrowa Wodą: powieść historyczna z XI wieku, Księgarnia Z. Gustowskiego, Poznań 1949.

Jakowska Krystyna, Podręczny słownik pisarzy polskich, Państwowe Wydawnictwo "Wiedza Powszechna", Warsaw 2006.

Kuncewicz Piotr, Leksykon polskich pisarzy współczesnych, vol. 1 (A-M), Graf-Punkt, Warsaw 1995.

Polska epika ludowa, S. Czernik (ed.), Zakład Narodowy im. Ossolińskich. Wydawnictwo we współpr. z De Agostini Polska, Wroclaw-Warsaw 2006.

Stownik pisarzy polskich, E. Zarych (ed.), Krakowskie Wydawnictwo Naukowe, Cracow 2008.

Współcześni polscy pisarze i badacze literatury, vol. 2 (C-F), J. Czachowska i A. Szałagan (eds.), Wydawnictwa Szkolne i Pedagogiczne, Warsaw 1994. 


\title{
Wiktor Gardocki
}

\section{Errata to the Stanisław Czernik's Biography: 1949}

\begin{abstract}
(Summary)
The subject of this paper is the writing activity of Stanisław Czernik in 1949. Czernik was an esteemed writer but concurrently he worked as censor in The Ministry of Culture and Art. He reviewed novels of many writers in the same department of Ministry where his novels were reviewed too. This paper discusses a number reviews wrote by Czernik and some reviews of Czernik' books wrote by another censors of The Ministry.
\end{abstract}

Keywords: Stanisław Czernik, Ministry of Culture and Art, censorship after 1945, censorhip towards literature, literary life after 1945, literary criticism. 